\title{
Governance and Human Development: The Impacts of Governance Indicators on Human Development
}

\author{
Ahmet Keser (Corresponding Author) \\ Assist. Prof. (PhD), Hasan Kalyoncu University, \\ Political Science and International Relations Dpt., Turkey \\ E-mail: ahmet.keser@hku.edu.tr or a123keser@gmail.com \\ Yunus Gökmen \\ Assoc.Prof. (PhD), Turkish Military Academy, Turkey \\ E-mail: yunusgokmen@gmail.com
}

Received: Dec. 20, 2017 Accepted: Jan. 9, 2018 Online published: Jan. 10, 2018

doi:10.5296/jpag.v8i1.12336 URL: https://doi.org/10.5296/jpag.v8i1.12336

\begin{abstract}
Throughout the article, the relation between the governance indicators and the Human Development Level (HDL) is investigated. The analysis is conducted by using Panel Data Regression Method. The valid annual data of World Governance Index between the years 2002-2012 for 33 member and candidate countries of European Union (EU) is collected from World Bank's official website. To measure HDL, data of Human Development Index (HDI) belonging to 2002-2012 term is gathered from United Nations Development Programme's official website. The analysis concluded that, at least three of the governance indicators as Government Effectiveness, Regulatory Quality and Rule of Law have significant positive coefficients in the panel data regression model. It means that better governance performance for any country provides better performance at the HDL. It is evaluated that the results of the research may provide useful instrument both for public policy designers and for academics.
\end{abstract}

Keywords: governance, human development, panel data regression, governance indicators, HDI indicators

\section{Introduction}

When looked back from the first quarter of the $21^{\text {st }}$ century, it is possible to see significant developments, especially affecting the previous conventional government mechanisms of the 
nation states and evolving it towards a governance perspective, and the previous public administration systems to a public management approach, which can be evaluated as a paradigm shift at the public administration discipline.

Governance can be handled in different levels from the global to national layer or from the national to local level and finally to organizational layer. Governance is now being applied to different areas from the water regimes to border security and/or to trade regimes as well. One of the most important aspects of governance is to examine it with a development perspective. For example according to Rodrik, Dani (2001:4): "Once one views the trade regime--and the governance challenges it poses--from a developmental perspective, it becomes clear that the governments of developing countries and many of the Northern NGOs share the same goals: policy autonomy to pursue one's own values priorities, poverty alleviation, and human development in an environmentally sustainable manner".

Investigating the mutual impacts of governance and human development has started after mid-1990s. In his study related to media, governance and development, Daniel Kaufmann (2005: 55-57) states that the World Bank believed that its mandate was limited to purely economic issues until the mid-1990s, and the importance of governance and strong institutions were underestimated by the Bank. According to the author (Kaufmann, 2005), the Bank became aware that poor governance and corruption were not only severe impediments to the effective use of development assistance, but that the poor were most affected by these abuses by the late 1990s.

The strong relation between the governance and human development was first brought into the agenda with an official report by United Nations Development Program (UNDP) in 1997. "Governance has become a hot topic as evidence mounts on the critical role it plays in determining societal well-being" (Graham, Amos and Plumptre, 2003:1) since then. In this UNDP - Human Development (HD) Report 1997- the issue is stated as "Better governance is vital not just to ensure the rule of law and protect against international organized crime, but also to maintain and expand social and economic infrastructure" (UNDP, 1997a:90). The report's main message is constructed on the struggle with the poverty and while giving this message, the basic dimensions of the human development are stated as poverty is no longer inevitable.

The Report clearly indicates that the world has the required material, natural resources, the know-how and the people to make a poverty-free world a reality in less than a generation. In the report UNDP constructs the possible relation between the governance and human development with the assessment as "Poverty has many faces. It is much more than low income. It also reflects poor health and education, deprivation in knowledge and communication, inability to exercise human and political rights and the absence of dignity, confidence and self-respect" (UNDP, 1997a: iii). Adel M. Abdellatif (2003:4) also states the central stage of the governance in the development discourse and it's being considered as the crucial element to be incorporated in the development strategy.

UNDP also evaluates governance as a useful tool in the prevention of the conflicts and thereby in the elimination of poverty. This need is stated with the following assessment as: 
"one of the main problem for poor households and communities caught up in conflict is the inadequacy of today's system of global governance-it simply was not designed for dealing with internal conflicts" (UNDP, 1997a:66). According to the report better governance is vital both to ensure the rule of law, and to maintain and expand social and economic infrastructure (UNDP, 1997a) as well. According to Klaus Dingwerth and Philipp Pattberg (2006:186) "we distinguish between two general uses of the concept: global governance as a set of observable phenomena, and global governance as a political program". The above assessments explain why "the UNDP has been at the forefront of providing assistance to governance programs in efforts to achieve sustainable human development" (UNDP, 2002:16).

Related to the national policies in an era of globalization, there is also a suggested strategy in the UNDP (1997a:89) HD report as: "to open more opportunities for the poorest countries, to ensure the equally sharing of benefits of global integration" and it is stated that the following six key policy options can become part of a strategy to reduce poverty and to empower the poor:

(1) Manage trade and capital flows more carefully,

(2) Invest in poor people,

(3) Foster small enterprises,

(4) Manage new technology,

(5) Reduce poverty and provide safety nets,

(6) Improve governance (UNDP, 1997a:90).

Another UNDP policy document also supports the role of governance in the improving progress of human development with the following statement: “...For it is only with good governance that we can find solutions to poverty, inequity and insecurity... UNDP believes that building the capacity for governance is central to sustainable human development" (UNDP, 1997b:2).

Moreover the policy paper claims that "a sustainable human development cannot be achieved without good governance and/or governance cannot be sound unless it sustains human development" (UNDP, 1997b:4), so the two terms: Governance and Human Development are as parts of a whole and indivisible.

\section{Governance and Human Development}

As we meet in many definitions of different terms in social sciences, there are a series of governance definitions approaching to the term through various perspectives. According to Abdellatif (2003:3), the definition of UNDP appears the most appropriate among the many definitions from the UN viewpoint. We also agree with the author since the definition handles the different layers of governance briefly, and successfully attaches the governance approach to human development. So if we look at this definition, UNDP defines governance as: "the exercise of political, economic and administrative authority in the management of a country's affairs at all levels...Governance includes the state, but transcends it by taking in the private 
sector and civil society. All three are critical for sustaining human development" (UNDP, 1997a:5-6). It is possible to follow the path of the relation between the governance and human development from this definition also but of course these claims should empirically be proved.

World Bank also points out this close relationship between the governance and development by indicating that governance is "the manner in which power is exercised in the management of a country's economic and social resources for development" (Holzer and Byong-Joon (eds), 2002). Abdellatif (2003:5) asserts that with the definition of World Bank "the concept of governance is concerned directly with the management of the development process, involving both the public and the private sectors".

Governance is of course not limited with the state or country level as stated earlier. We can also refer to the statement as: "Governance is about the more strategic aspects of steering: the larger decisions about direction and roles. That is, governance is not only about where to go, but also about who should be involved in deciding, and in what capacity" (Graham, Amos and Plumtre, 2003:2) to indicate the conceptual frame of governance related to planning and decision making progress in addition to its roles in application phase. The authors assess that there are four areas or zones where the concept is particularly relevant: (1) Governance in 'global space' or global governance, (2) Governance in 'national space', (3) Organizational governance and (4) Community governance (Graham, Amos and Plumtre, 2003:2-3).

Related to the roles of main players at different layers of governance, UNDP makes the following assessment: "The state creates a conducive to political and legal environment. The private sector generates jobs and income. And civil society facilitates political and social interaction - mobilizing groups to participate in economic, social and political activities. Because each has weaknesses and strengths, a major objective of our support for good governance is to promote constructive interaction among all three" (UNDP, 1997b:6). According to Graham, Amos and Plumtre (2003:1), governance is partly "about how governments and other social organizations interact, how they relate to citizens, and how decisions are taken in a complex world. Thus governance is a process whereby societies or organizations make their important decisions, determine whom they involve in the process and how they render account". UNDP (1997b:16) asserts that "Each domain of governance the state, the private sector and civil society - has a unique role in promoting sustainable human development". So with the wording of Abdellatif (2003:4), it is possible to make an assessment that "good governance is essential for successful development".

UNDP (1997b:10) defines human development as expanding the choices for all people in society. According to the report, with the governance approach, the men and women -particularly the poor and vulnerable- are the focus of the development process.

Supachet Chansarn (2014:3) states that the indictors used to measure human development are: "gross national income per capita, life expectancy, mean years of schooling and expected years of schooling. In addition, the resources are measured by three indicators including carbon dioxide emission per capita, electric power consumption per capita and energy use per capita". If we look back to its 20 year history, we see that human development level has 
become a widely used system for comparisons of welfare, which is linked to its grounding in multidimensional well-being measurement as well as to its transparency and simplicity (Harttgen and Klasen, 2012:878).

The above assessments do not prevent the current measurement of human development index (HDI) to receive many criticisms. For example "one of the most serious weaknesses of the HDI is that it does not take into account the distribution of human development within a country" (Harttgen and Klasen, 2012:878) and/or "it does not take into account inequality within countries" (Grimm et.al., 2008:2527). According to Antony Davies (2009:327), the criticisms of the HDI fall into three groups: "criticisms of the conceptual definition of human development, criticisms of the specific equations that generate the HDI, and criticisms of the quality of the data used in the HDI calculations". Consequently for better results, development levels should not be assessed by income measures alone, rather should consider both social and human welfare criteria (Adler, Yazhemsky and Tarverdyan, 2010:73) as well. Stephen Morse (2003:281) also indicates another handicap of the values of the HDI for each country which have been presented in the Human Development Reports (HDRs) since 1990. According to him, even if the methodology is consistent for all countries in each year, there are notable differences between years and this phenomenon causes difficulty in temporal comparisons of progress (Morse, 2003:281). Even there are certain criticisms which can provide further enhancement, the current indicators and data about the human development level of the countries still preserves its situation of presenting a useful tool for related researches.

After indicating the criticisms to the HDI process, it is time to return to the appearance of the current HDI progress for having a frame for our research. According to UNDP, there are five aspects to sustainable human development - all affecting the lives of the poor and vulnerable:

Empowerment - The expansion of men and women's capabilities and choices increases their ability to exercise those choices free of hunger, want and deprivation. It also increases their opportunity to participate in, or endorse, decision making affecting their lives.

Co-operation - With a sense of belonging important for personal fulfillment, well-being and a sense of purpose and meaning, human development is concerned with the ways in which people work together and interact.

Equity - The expansion of capabilities and opportunities means more than income - it also means equity, such as an educational system to which everybody should have access.

Sustainability - The needs of this generation must be met without compromising the right of future generations to be free of poverty and deprivation and to exercise their basic capabilities.

Security - Particularly the security of livelihood - People need to be freed from threats, such as disease or repression and from sudden harmful disruptions in their lives (UNDP, 1997b:10-11). 
To sum up with the UNDP perspective: "Governance has three legs: economic, political and administrative. Economic governance includes decision-making processes that affect a country's economic activities and its relationships with other economies. It clearly has major implications for equity, poverty and quality of life. Political governance is the process of decision-making to formulate policy. Administrative governance is the system of policy implementation. Encompassing all three, good governance defines the processes and structures that guide political and socio-economic relationships" (UNDP, 1997b:12-13).

Later in 2002 decentralization is also studied in a conference as an inevitable mechanism within this frame. According to the conference paper "decentralization is a challenging complex process that requires patience and dedication on the part of all the stakeholders, but it also promises to be a mechanism for improved democratic governance and sustainable human development" (UNDP, 2002:16).

\section{The Characteristics of Good Governance}

UNDP clearly puts forward that, the State, civil society and the private sector as being the institutions of governance in three domains must be designed to contribute to sustainable human development and till now much has been written about the characteristics of efficient government, successful businesses and effective civil society organizations, but the characteristics of good governance defined in societal terms remain elusive. With this explanation UNDP specifies the characteristics as the following: (1) Participation, (2) Rule of law, (3) Transparency, (4) Responsiveness (Institutions and processes try to serve all stakeholders) (UNDP, 1997b:14), (5) Consensus orientation (Good governance mediates differing interests to reach a broad consensus...), (6) Equity (All men and women have opportunities to improve or maintain their well-being), (7) Effectiveness and efficiency (... results that meet needs while making the best use of resources), (8) Accountability (All decision-makers ... are accountable to the public and to institutional stakeholders...), (9) Strategic vision (UNDP, 1997b:15).

According to Abdellatif (2003:6) "the concept of good governance has been clarified by the work of the Commission on Human Rights with its resolution 2000/64" which links "good governance to an enabling environment conducive to the enjoyment of human rights and prompting growth and sustainable human development". So as mentioned by the author "the resolution stands as an implicit endorsement of the rights-based approach to development". In principle, the concept of governance may be applied to any form of collective action (Graham, Amos and Plumptre, 2003:2).

At this stage, our task is not just to accept the assessments of UNDP and/or World Bank blindly, but instead to examine empirically to see if really there are any relations between governance indicators and Human Development Levels (HDL).

\section{Data Collection and Method}

In this research, the valid annual data of World Governance Index for the period of 2002-2012 belonging to 33 member and candidate countries of European Union (EU) Austria, Belgium, Bulgaria, Croatia, Cyprus, Czech Republic, Denmark, Estonia, Finland, 
France, Germany, Greece, Hungary, Iceland, Ireland, Italy, Latvia, Lithuania, Luxembourg, Macedonia (FYR), Malta, Montenegro, Netherlands, Poland, Portugal, Romania, Serbia, Slovak Republic, Slovenia, Spain, Sweden, Turkey and United Kingdom - is collected from The World Bank official website (World Bank, 2015).

In order to measure HDL we use Human Development Index (HDI) -a composite measurement including education, literacy, and income component- data belonging to 2002-2012 term is gathered from United Nations Development Program formal website (UNDP, 2015). The descriptive statistics of the data is presented in Appendix A.

In this study, in order to scrutinize the explanatory power of independent variables (the sub-dimensions of World Governance Index) on dependent variable (HDI), we conduct panel data regression for EU-33 countries for the period of 2002-2012. Since the variables in the regression model have different measurement units (e.g. HDI: 0.000-1.000 point, The sub-dimensions of World Governance Index: (-)2,5-(+)2,5), we propose logarithmic panel data (time-series cross-section) regression model as expressed in Equation 1.

$$
\ln H D I_{i t}=\beta_{0}+\beta_{1} \ln C C_{i t}+\beta_{2} \ln G E_{i t}+\beta_{3} \ln P V_{i t}+\beta_{4} \ln R Q_{i t}+\beta_{5} \ln R L_{i t}+\beta_{6} \ln V A_{i t}+\varepsilon_{i t}
$$

InHDI $_{i t}$ : The natural logarithm of HDI Score of $i^{\text {th }}$ country related to $t^{\text {th }}$ term.

$\operatorname{lnCC}_{i t} \quad$ : The natural logarithm of Control of Corruption Sub-dimension Score of $i^{\text {th }}$ country related to $t^{\text {th }}$ term.

$\ln \boldsymbol{G E}_{i t} \quad$ : The natural logarithm of Government Effectiveness Sub-dimension Score of ith country related to th term.

$\ln \boldsymbol{P} V_{i t} \quad$ : The natural logarithm of Political Stability and Absence of Violence/Terrorism Sub-dimension Score of ith country related to tth term.

$\ln R Q_{i t} \quad$ : The natural logarithm of Regulatory Quality Sub-dimension Score of $i^{\text {th }}$ country related to $t^{\text {th }}$ term.

$\ln R L_{i t} \quad$ : The natural logarithm of Rule of Law: Sub-dimension Score of $i^{\text {th }}$ country related to $t^{\text {th }}$ term.

$\operatorname{lnVA}_{\text {it }} \quad$ : The natural logarithm of Government Effectiveness Sub-dimension Score of $i^{\text {th }}$ country related to $t^{\text {th }}$ term.

$\varepsilon_{i t} \quad:$ is the error (residual) term in the panel data regression model.

\section{Econometric Analysis}

The base objective of our study is to research whether there is a relationship of sub-dimensions of WGI on HDI in EU-33 countries for 2002-2012 terms by using panel data regression. Panel data analysis is widely used for last decade and basic form of panel data regression differs from a regular time-series or cross-section regression in that it has a double subscript on its variables as illustrated in Equation 2 (Baltagi, 2005:11).

$$
y_{i t}=\alpha+X_{i t}^{\prime} \beta+u_{i t} \quad i=1, \ldots, N ; \quad t=1, \ldots, T
$$

with i indicating households, countries, firms etc. and t expressing time. The i subscript, expresses the cross-section dimension whereas $t$ donates the time-series dimension. $\alpha$ is a scalar, $\beta$ is $\mathrm{K} \times 1$ and $\mathrm{Xit}$ is the $\mathrm{it}^{\text {th }}$ observation on $\mathrm{K}$ explanatory variables and uit is error term. 
At firstly, to achieve our objective in this study, we check whether all series in the panel regression model stationary by using panel unit root test and we conduct panel data regression.

Panel Unit Root Test. In panel data regression, firstly, the panel unit root test must be employed for describing whether the related variables are stationary. If these variables are non-stationary, it may cause to emerging of spurious regressions in regression analysis (Baltagi, 2005:237). Two types of panel unit root tests are accepted widely in literature. If the persistent parameters are common across cross-section, this type of process is entitled as common unit root test. Levin, Lin and Chu (LLC) (2002) improved a common unit root process by using this assumption. On the other hand, if the persistent parameters freely move across cross section, this type of unit root process is named as individual unit root process. The IPS (Im, Pesaran and Shin, 2003), Fisher-ADF and Fisher-PP tests are based on this assumption. The common and individual unit root tests' results are presented in Table 1.

Table 1. Results of Panel Unit Root Test***

\begin{tabular}{|c|c|c|c|c|c|c|c|c|}
\hline \multirow[b]{3}{*}{ Variables } & \multirow{2}{*}{\multicolumn{2}{|c|}{$\begin{array}{c}\begin{array}{c}\text { Common Unit Root } \\
\text { Test }\end{array} \\
\text { Levin Lin \&Chu }\end{array}$}} & \multicolumn{6}{|c|}{ Individual Unit Root Tests } \\
\hline & & & \multicolumn{2}{|c|}{ Im, Pesaran and Shin } & \multicolumn{2}{|c|}{$\begin{array}{l}\text { ADF Fisher } \\
\text { Chi-square }\end{array}$} & \multicolumn{2}{|c|}{$\begin{array}{l}\text { PP Fisher } \\
\text { Chi-square }\end{array}$} \\
\hline & Statistic & $\mathrm{p}$ & Statistic & $\mathrm{p}$ & Statistic & $\mathrm{P}$ & Statistic & $\mathrm{p}$ \\
\hline \multicolumn{9}{|c|}{ Level } \\
\hline $\ln H D I$ & -9.2692 & $0.0000 *$ & -7.1671 & $0.0000 *$ & 178.92 & $0.0000 *$ & 183.38 & $0.0000 *$ \\
\hline $\ln C C$ & -5.1376 & $0.0000 *$ & -2.2063 & $0.0137 * *$ & 103.46 & $0.0022 *$ & 140.77 & $0.0000^{*}$ \\
\hline $\ln G E$ & -6.9813 & $0.0000^{*}$ & -3.1248 & $0.0009 *$ & 115.34 & $0.0002 *$ & 102.99 & $0.0024 *$ \\
\hline $\ln P V$ & -7.9276 & $0.0000^{*}$ & -3.8103 & $0.0001 *$ & 120.02 & $0.0001 *$ & 116.29 & $0.0001 *$ \\
\hline $\ln R Q$ & -13.805 & $0.0000 *$ & -7.3254 & $0.0000 *$ & 183.23 & $0.0000 *$ & 222.06 & $0.0000 *$ \\
\hline $\ln R L$ & -7.1909 & $0.0000^{*}$ & -2.1690 & $0.0150 * *$ & 97.692 & $0.0068^{*}$ & 113.47 & $0.0003 *$ \\
\hline $\ln V A$ & -4.6468 & $0.0000^{*}$ & -1.9170 & $0.0276^{* *}$ & 93.694 & $0.0141 * *$ & 95.49 & $0.0198 * *$ \\
\hline
\end{tabular}

Null Hypothesis: Unit Root

The p-values indicated $(*)$ and $(* *)$ are significant at $\quad=0.01$ and $\quad=0.05$ level respectively. (***): Probabilities for Fisher tests are computed using an asymptotic Chi-square distribution. All other tests assume asymptotic normality. Automatic lag length selection based on SIC

It can be concluded from the results in Table 1 that all variables are stationary in level form. It refers that the null hypothesis is rejected at $\alpha=0.01$ significance level for all variables. Consequently, we can employ panel data regression for the model expressed in Equation 1.

Hausman's Specification Test. In panel data regression, one of the main challenges of a researcher is: To evaluate which model is better, "Fixed Effects" or "Random Effects"? If it is supposed that error component $\varepsilon_{i t}$ and the $X_{i t}$ 's are uncorrelated $\left(E\left(\varepsilon_{i t} / X_{i t}\right)=0\right)$, Random Effects (RE) may be appropriate and if $\varepsilon_{i t}$ and the $X_{i t}$ 's are correlated $\left(E\left(\varepsilon_{i t} / X_{i t}\right) \neq 0\right.$ ), Fixed Effects (FE) may be proper. 


\section{Macrothink}

Journal of Public Administration and Governance

ISSN 2161-7104

2018, Vol. 8, No. 1

Because, if the individual error component $\varepsilon_{\text {it }}$ and one or more regressors are correlated, the RE estimators are biased and whereas FE estimators are unbiased (Gujarati: 2004). Thus, it is important to have a method for examining this assumption. Hausman (1978) proposed a test based on the difference between the random effects and fixed effects' estimates, and named "The Hausman test". This test provides a statistically significant difference for examining the random effects assumption (Wooldridge, 2002:288).

Model Estimation and Results. Hausman test is conducted and according to the test result indicated in Table 2, it can be concluded that the null hypothesis "supposing random effects model is appropriate" is significantly rejected. In summary, we describe that the FE specification is more proper than RE specification. The Random Effects (OLS) specification's results are indicated in Table 2 below:

Table 2. Panel Data Regression Summary

\begin{tabular}{lcc}
\hline Coefficients & & Model (FE) \\
\hline & Constant $\left(\beta_{0}\right)$ & 1.719337 \\
& & $(168.0508)^{*}$ \\
& $\operatorname{lnCC}\left(\beta_{1}\right)$ & 0.001892 \\
& $\operatorname{lnGE}\left(\beta_{2}\right)$ & $(0.520265)$ \\
& $\operatorname{lnPV}\left(\beta_{3}\right)$ & 0.012588 \\
& & $(2.930016)^{*}$ \\
& $\operatorname{lnRQ}\left(\beta_{4}\right)$ & -0.002966 \\
& & $(-1.067583)$ \\
& $\operatorname{lnRL}\left(\beta_{5}\right)$ & 0.010298 \\
& $\operatorname{lnVA}\left(\beta_{6}\right)$ & $(2.157310)^{* *}$ \\
& & 0.012412 \\
Sample & & $(2.072478)^{* *}$ \\
Periods & & -0.011215 \\
Observations & & $(-1.770317)$ \\
$\mathrm{R}^{2}$ & & 33 countries \\
Adjusted $\mathrm{R}^{2}$ & & 11 \\
\hline F & & 363 \\
\hline Hausman Test & & 0.8151 \\
Heteroscedasticity Wald $\left(\chi^{2}\right)$ & 0.8121 \\
Autocorrelation $($ Baltagi-Wu LBI Test $)$ & $261.6363^{*}$ \\
\hline
\end{tabular}

For examining if there is an autocorrelation in the model, we perform a simple test improved by Baltagi and Wu (1999) and we infer that there is no autocorrelation problem in the models. To test heteroscedasticity in the model, we conduct a modified Wald test for group wise heteroscedasticity announced by Greene (2003:323) and conclude that there is no heteroscedasticity in the models according to the results in Table 2.

Fixed Effects regression model is significant at $\alpha=0.01$ As regards the adjusted $\mathrm{R}^{2}$, the FE model have high explanatory power $(0.812)$. For examining the effects of the sub-dimensions of WGI over HDI comprehensively, the coefficients of regression model are indicated in Table 2. According to t-statistics constant and some coefficients (lnGE, lnRQ and lnRL) in 
the regression model are significant at $5 \%$ significance level. But the others $(\operatorname{lnCC}, \operatorname{lnPV}$ and $\operatorname{lnVA}$ ) are not significant at 5\% significance level. It can be deduced that there is a proper specification for the model.

Cross-Section Fixed Effects are presented in Table 3 below:

Table 3. Cross-Section Fixed Effects (Dummy Variables)

\begin{tabular}{clrrlr}
\hline ID & Countries & Effects $\left(\eta_{i}\right)$ & ID & \multicolumn{1}{c}{ Countries } & Effects $\left(\eta_{i}\right)$ \\
\hline $\mathbf{1}$ & Austria & 0.002014 & $\mathbf{1 8}$ & Lithuania & -0.004098 \\
$\mathbf{2}$ & Belgium & 0.006845 & $\mathbf{1 9}$ & Luxembourg & 0.003784 \\
$\mathbf{3}$ & Bulgaria & -0.009324 & $\mathbf{2 0}$ & Macedonia $(\boldsymbol{F Y R})$ & -0.016298 \\
$\mathbf{4}$ & Croatia & -0.005666 & $\mathbf{2 1}$ & Malta & -0.001983 \\
$\mathbf{5}$ & Cyprus & -0.003009 & $\mathbf{2 2}$ & Montenegro & -0.003137 \\
$\mathbf{6}$ & Czech Republic & 0.004387 & $\mathbf{2 3}$ & Netherlands & 0.008504 \\
$\mathbf{7}$ & Denmark & 0.004043 & $\mathbf{2 4}$ & Poland & -0.002301 \\
$\mathbf{8}$ & Estonia & -0.001737 & $\mathbf{2 5}$ & Portugal & -0.004536 \\
$\mathbf{9}$ & Finland & 0.004188 & $\mathbf{2 6}$ & Romania & -0.006085 \\
$\mathbf{1 0}$ & France & 0.005723 & $\mathbf{2 7}$ & Serbia & -0.008579 \\
$\mathbf{1 1}$ & Germany & 0.008426 & $\mathbf{2 8}$ & Slovak Republic & -0.000198 \\
$\mathbf{1 2}$ & Greece & 0.005787 & $\mathbf{2 9}$ & Slovenia & 0.002455 \\
$\mathbf{1 3}$ & Hungary & -0.001781 & $\mathbf{3 0}$ & Spain & 0.005131 \\
$\mathbf{1 4}$ & Iceland & 0.007504 & $\mathbf{3 1}$ & Sweden & 0.008547 \\
$\mathbf{1 5}$ & Ireland & 0.009610 & $\mathbf{3 2}$ & Turkey & -0.021698 \\
$\mathbf{1 6}$ & Italy & 0.007974 & $\mathbf{3 3}$ & United Kingdom & 0.002301 \\
$\mathbf{1 7}$ & Latvia & -0.006791 & & & \\
\hline
\end{tabular}

Notes: t- statistics are showed in parenthesis. The test values indicated (*) and (**) are significant at $=0.01$ and $=0.05$ level respectively. $(* * *)$ : Null Hypothesis is Random Effects model. The null hypothesis is rejected at $=0.01$ level.

(\$) : A modified Wald test for groupwise heteroscedasticity is performed for heteroscedasticity (see Greene, 2003: 323). Null Hypothesis: There is heteroscedasticity in the model. The null hypothesis is rejected at $\quad=0.01$ level.

(A) : Baltagi-Wu LBI test for autocorrelation in panel data is used (see Baltagi, 2005: 89-91). Null Hypothesis: No first-order autocorrelation. The null hypothesis is accepted $=0.01$ level.

The sign of the coefficients are compatible with our theory based on literature. In the theory we develop, our expectation for dependent/independent variables is that the more increase in independent variables, the more decrease in dependent variable. In panel data regression model, higher GE, RQ and RL cause to increase in HDI. Namely, one percent change in GE induces 0.013 percent change, one percent change in RQ causes 0.010 percent change and similarly one percent change in RL induces 0.012 percent change in HDI in the same direction other things being equal. The relationship between dependent and independent variables is presented in Figure 1. 


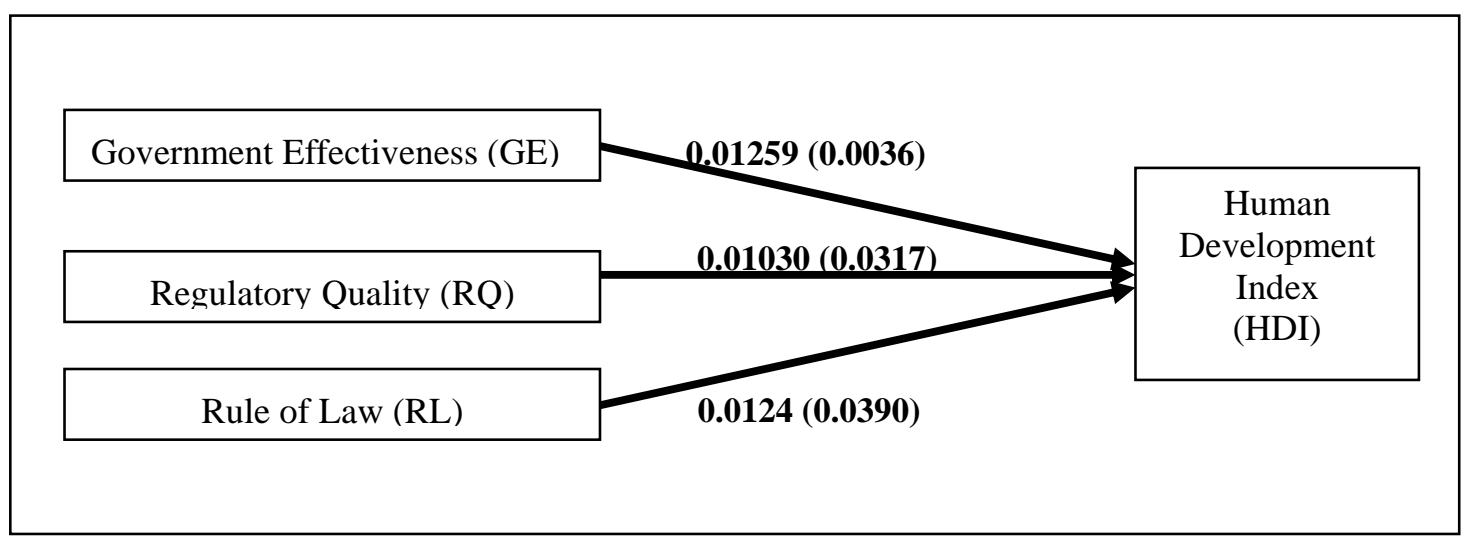

Figure 1. Statistically supported longitudinal associations among research variables

The term "fixed effects" refers that the intercept may differ across individuals (here the 33 countries), each individual's (country) intercept does not change over time (Gujarati, 2004:642). In our study, due to fixed effects model, every country have different intercept $(\beta 0)$ and one can infer from the findings in Table 3 that the countries (Austria, Belgium, Czech Republic, Denmark, Finland, France, Germany, Greece, Iceland, Ireland, Italy, Luxembourg, Netherlands, Slovenia, Spain, Sweden and United Kingdom) which are mostly earlier members of the EU with an improved governance strategy have positive dummy values. It means that these countries always have higher HDI values then the others by taking the panel data regression equations into consideration.

\section{Conclusion and Discussion}

Finally, after examining the results of the analysis it is possible to make an assessment as: a sin qua non necessity for the prospective high human development level of any nation state seems to be an improved governance mechanism with all its prerequisites as transparency, voice and accountability, effectiveness, regulatory quality, political stability and control of corruption. Because as can be seen in Figure 1, at least three of the coefficients for governance indicators as Government Effectiveness, Regulatory Quality and finally Rule of Law have a significant correlation with the Human Development Level of any country from the sample group, mainly 33 member and candidate countries of the European Union. We assess that by the time all the components may have a similar statistical relation when we have sufficient data for a longer period.

Another finding of our study, which proves evidence that the better governance strategies and performance for any country means a better performance at the Human Development Level as well. That's why the earlier members of the EU, in other words, relatively higher governance performing countries as Austria, Belgium, Czech Republic, Denmark, Finland, France, Germany, Greece, Iceland, Ireland, Italy, Luxembourg, Netherlands, Slovenia, Spain, Sweden and United Kingdom, have higher HDI values then the others by taking the panel data regression equations into consideration. This finding is also consistent with the current literature. For example, Serkan Gürlük (2009:2327) applied a modified human development index (MHDI) to measure the effects of human development on the economic development paths of Mediterranean countries. According to the results of his study, all countries follow 
increasing logarithmic or inverse-logarithmic curves that keep on the industrial pollution path apart from France. So the author states that the outcomes of the research pointed out "the differences between the Northern and Southern Mediterranean" and concludes that "human development should be the first objective of economic development in the Southern countries of the Mediterranean" (Gürlük, 2009:2327). So this research also provides support related to the positive correlation between the governance level and human development level for a country.

Another study conducted by Owen and Yawson (2010:689) also has an explanatory quality about why a high HDI level means a higher foreign investment capacity for a country, consequently why the foreign investors prefer to invest in more developed countries. The authors "examine the role of human development in US companies' decisions to engage in cross border acquisitions" in their study. They find after their research that "US firms make acquisitions in countries with strong HDI levels". So their research also provides evidence "to explain why so little capital flows from developed to developing economies" and implicitly from those with high governance levels to those which has lower governance indicators. Last but not least as stated by Tom Farer "More generally, a state with a vision of national interest that emphasizes schemes of mutually advantageous cooperation with other states is likely to play a much larger role in the evolution of global governance than one similarly endowed in terms of wealth or military capacity..." (Farer, 2011:283).

Consequently, because of the structured HDI sub-dimensions [gross national income per capita, longevity (life expectancy at birth and index of population health), mean years of schooling and expected years of schooling], HDI is history dependent and can be improved in a slow manner. So the governance indicators, mainly Government Effectiveness, Regulatory Quality and Rule of Law, should be improved consistently by governments in order to increase HDI scores.

\section{Limitations and Recommendations for Future Studies}

We have to denote that this analysis and interpretations are limited to the 33 EU countries' data for 12 years period between 2002 and 2012. So, significant and long term associations among the variables may not be valid for another time frame or other countries in the world. We also have to denote that the findings in this study are probabilistic. All above mentioned limitations of this study should be born in mind before making generalization. For future studies we can suggest that the researchers should enlarge data dimension by including the other countries in order to test long term associations between sub-dimensions of WGI and HDI.

\section{References}

Abdellatif, A. M. (2003). Good Governance and its Relationship to Democracy \& Economic Development, Global Forum III on Fighting Corruption and Safeguarding Integrity (Seoul 20-31 May 2003). 
Adler, N., Ekaterina, Y., \& Ruzanana, T. (2010). A framework to measure the relative socio-economic performance of developing countries, Socio-Economic Planning Sciences, 44, 73-88. https://doi.org/10.1016/j.seps.2009.08.001

Baltagi, B. H. (2005). Econometric Analysis of Panel Data, (Third Edition), John Wiley \& Sons Ltd, England.

Baltagi, B. H., \& Wu, P. X. (1999). Unequally spaced panel data regressions with AR (1) disturbances, $\quad$ Econometric Theory, 15, 814-823. https://doi.org/10.1017/S0266466699156020

Chansarn, S. (2014). The Evaluation of the Sustainable Human Development: A Cross-Country Analysis Employing Slack-Based DEA, Procedia Environmental Sciences, 20, 3-11. https://doi.org/10.1016/j.proenv.2014.03.003

Davies, A. (2009). Human development and the optimal size of government, The Journal of Socio-Economics, 38, 326-330. https://doi.org/10.1016/j.socec.2008.07.015

Dingwerth, K., \& Pattberg, P. (2006). Global Governance as a Perspective on World Politics, Global Governance, 12, 185-203.

Farer, T. (2011). Introduction, Global Governance, 17, 281-284.

Graham, J., Bruce, A., \& Tim, P. (2003). Principles for Good Governance in the 21st Century, Policy Brief No.15, (The Institute on Governance (IOG), Ottawa, Canada, August 2003).

Greene, W. (2003). Econometric Analysis, Fifth Edition, Prentice-Hall, Upper Saddle River, New Jersey.

Grimm, M., Kenneth, H., Stephan, K., \& Mark, M. (2008). A Human Development Index by Income Groups, World Development, 36(12), 2527-2546. https://doi.org/10.1016/j.worlddev.2007.12.001

Gujarati, D. N. (2004), Basic Econometrics, 4th Ed., Mcgraw-Hill. USA.

Gürlük, S. (2009). Economic growth, industrial pollution and human development in the Mediterranean Region, Ecological Economics, 68, 2327-2335. https://doi.org/10.1016/j.ecolecon.2009.03.001

Harttgen, K., \& Stephan, K. (2012). A Household-Based Human Development Index, World Development, 40(5), 878-899. https://doi.org/10.1016/j.worlddev.2011.09.011

Hausman, J. A. (1978). Specification Tests in Econometrics, Econometrica, 46, 1251-1271. https://doi.org/10.2307/1913827

Holzer, M., \& Kim, B. J. (eds). (2002). Building Good Governance: Reforms in Seoul, (National Center for Public Productivity, 2002), Preface.

Im, K. S., Pesaran, H., \& Shin, Y. (2003). Testing for Unit Roots in Heterogeneous Panels, Journal of Econometrics, 115, 53-74. https://doi.org/10.1016/S0304-4076(03)00092-7 


\section{Macrothink}

Journal of Public Administration and Governance ISSN 2161-7104 2018, Vol. 8, No. 1

Kaufmann, D. (2005). Media, Governance and Development: An Empirical Perspective that Challenges Convention in Media Metters: Perspectives on Advancing Governance \& Development from the Global Forum for Media Development, ed. Mark Harvey, (published by Internews Europe on behalf of the Global Forum on Media Development (GFMD), October 2005).

Levin, A., Lin, C. F., \& Chu, C. S. J. (2002). Unit Root Test in Panel Data: Asymptotic and Finite Sample Properties, Journal of Econometrics, 108, 1-24. https://doi.org/10.1016/S0304-4076(01)00098-7

Morse, S. (2003). For better or for worse, till the human development index do us part?, Ecological Economics, 45, 281-296. https://doi.org/10.1016/S0921-8009(03)00085-5

Owen, S., \& Alfred, Y. (2010). Human development and cross-border acquisitions, Journal of Empirical Finance, 17, 689-701. https://doi.org/10.1016/j.jempfin.2010.03.004

Rodrik, D. (2001). The Global Governance of Trade as if Development Really Mattered, in the Report submitted to the UNDP July 2001, (Harvard University, John F. Kennedy School of Government, 79 Kennedy Street, Cambridge, MA 02138, July 2001).

UNDP. (1997a). Human Development Report 1997, (Oxford University Press, New York, 1997a).

UNDP. (1997b). Governance for Sustainable Human Development, Governance - related UNDP documents - UNDP Governance policy paper.

UNDP. (2002). Overview of Decentralisation Worldwide: A Stepping Stone to Improved Governance and Human Development, 2nd International Conference on Decentralisation, Federalism: The Future of Decentralizing States? Manila, Philippines 25-27 July 2002, (UNDP New York, 2002).

UNDP. (2015). Human Development Reports (1990-2014) [also Data File]. Retrieved on (January 20, 2015), Available online at http://hdr.undp.org/en/data

Wooldridge, J. M. (2002). Econometric Analysis of Cross Section and Panel Data, The MIT Press, London, England.

World Bank. (2015), The Worldwide Governance Indicators (WGI), Retrieved on (February 7 , 2015), Available online at http://info.worldbank.org/governance/wgi/index.aspx\#reports.

\section{Copyright Disclaimer}

Copyright for this article is retained by the author(s), with first publication rights granted to the journal.

This is an open-access article distributed under the terms and conditions of the Creative Commons Attribution license (http://creativecommons.org/licenses/by/4.0/). 